establishments have been harassed by lack of funds, so that newspapers have been full of tales of researchers who have been put out to grass or who have fled abroad. Young people, who read the newspapers, have also learned from them that entrants to other professions, that of providing financial services, for example, are likely to live more prosperously, and have voted with their feet. That there is a shortage of putative graduate students is not in the least surprising, but a predictable consequence of the market forces on which the British government bases most of its policies, sometimes successfully. It is even more worrying that the past few years have probably frightened away an unduly large proportion of the most able people.

There is now no quick remedy. The Medical Research Council's plan to offer graduate students on its books an extra $£ 500$ a year, commendable enough, is about as relevant to the underlying market forces as would be a great man's attempt to interfere with the diurnal tides by walking into the sea (which is what King Canute demonstrated nine centuries ago). Even doubling the present meagre stipend would have little beneficial effect. Only when the practice of research in Britain has been shown again to be an honoured as well as an honourable profession will young people be clamouring for the studentships on offer.

That calculation should be central in the planning of how to spend the extra sums for research now being made available. But that appears not to have been the case. Too much of the extra is being spent on directed research or, worse, on the research councils' own establishments, too little on the means (research grants) by which individuals might make a mark and thus fire the imagination of young people choosing a career. Researchers should fight to see this balance redressed, knowing that in doing so they will be serving the wider British national interest.

Meanwhile, as a stop-gap remedy, the research councils might think of offering their studentships to young people from abroad, coupled with work permits to stay in Britain permanently. In the United States, for different reasons afflicted by a shortage of young researchers, the stratagem works well enough.

\section{Satanic violences}

The Shiite threat to kill a British author and the violence of animal rights extremists have a lot in common.

Mr Salman Rushdie's book Satanic Verses opens with the fantasy of how two unremarkable people survive the destruction (by a bomb) of an aircraft over the English Channel and then found a new religion. The ways of the Shiite Muslims who have now offered a money prize for Rushdie's assassination and those of the people who advocate civil rights for animals may seem only remotely connected, but they are nevertheless worth remarking.

Apart from the bomb last week at the University of
Bristol (remarkable only for being the first use of high explosives to damage British property in this particular cause) and the occupation of a crane on a Berkeley construction site, this has been a relatively quiet week, yet in their character the protests on behalf of animals have precisely the qualities that make the threats against Rushdie as offensive as they are.

First, it must be clear that the Shiite threat is an act of violence. One apologist last week is quoted as saying that "the arrow . . . is already travelling to his heart", by which is presumably meant that the threat will be regarded for decades to come as an invitation to some impressionable assassin to push the arrow home. The more tangible violence of the extremists in the animal rights movements has the same implacable quality; nothing, especially not reason, can divert it. It has the same quality of detachment from the identities of those who are injured; Shiites imprison random Western travellers to Beirut for years on end, while the explosion of a bomb at the University of Bristol is similarly random (but there is a veterinary school there). Why pick on that rather than on some other British university? Because it happened to be handy, perhaps?

As with the case of Rushdie so on the animal rights front, the most urgent need is that the moderates who believe that Rushdie's book is blasphemous (to Muslims) or that animals are misused in research should clearly dissociate themselves from the actions of the extremists. At least in the use of animals in research, the moderates have a powerful case, not least in their demands that people's use of animals should be as sparing as possible and that humane procedures should be followed. Failure to condemn these acts of violence has two consequences; the extremists are excited, while the moderate case is so tarnished by its association with violence that it is dangerously weakened. Sadly, that lesson seems not yet to have been learned, either in the case of Rushdie's book or that of the bomb at Bristol.

\section{Unfamiliar disguises}

The unfamiliar appearance of this issue of Nature implies no systematic change of content.

REGULAR readers who happen to notice the typographical changes in this week's format will passionately resent the small changes which have been made. That at least is what past experience shows. The only comfort is that, with the passage of a few weeks, the same readers will become just as vigilant in the defence of what is now offered - a layout which is generally more uniform, in particular respects more workable and which may help to make some sections of Nature more readable. No attempt has been made, on this occasion, to introduce fancy typographical tricks or even to restore the couplet from Wordsworth's "Endymion" from which this journal's name was taken in 1869. 